\title{
Historia del sifilítico marido de una feminista
}

\section{History of the Syphilitic Husband of a Feminist}

\author{
Ana Lidia García Peña \\ (D) https://orcid.org/0000-0002-1022-9007 \\ Facultad de Humanidades \\ Universidad Autónoma del Estado de México, México. \\ analidiag@prodigy.net.mx
}

Resumen: Historia de las etapas de subjetivación de Rafael Montes de Oca (1863-ca. 1930) quien estuvo enfermo de sífilis por más de 30 años y no obstante la marginación de ser condenado como "sifilítico degenerado" por las políticas higienistas de la época, logró aplicar las tecnologías del yo, según los planteamientos de Michel Foucault, y vivió distintos procesos de subjetivación procesual al redefinir su identidad, cuidar de sí mismo, casarse y convertirse en artista según el "Nuevo paradigma estético" de Felix Gauttari. En otro proceso de transformación, después de diez años de ser esposa-enfermera del sifilítico, María Ríos Cárdenas se convirtió en una famosa feminista durante su divorcio. Esta historia de subjetivación no sólo explica cómo un individuo confrontó las políticas de salud pública del porfiriato y la posrevolución, sino que también establece conexiones entre los cambios de una vida personal y las transformaciones en la vida pública de México.

Palabras clave: subjetivación procesual; sífilis; higienismo; divorcio; feminismo.

cómo citar: García Peña, A. L. (2019). Historia del sifilítico marido de una feminista. Secuencia (104), e1601. DOI: https://doi.org/10.18234/secuencia.v0i104.1601

cC Esta obra está protegida bajo una Licencia Creative Commons Atribución-NoComercial 4.0 Internacional. 
Abstract: History of the stages of subjectivization of Rafael Montes de Oca (1863-ca. 1930) who suffered from syphilis for over 30 years and despite the marginalization of being condemned as "degenerated syphilitic" by the hygienist policies of the time, managed to apply the technologies of the self, according to the approaches of Michel Foucault, and experienced various processes of procedural subjectivization by redefining his identity, taking care of himself, getting married and becoming an artist according to Felix Gauttari's "New aesthetic paradigm". In another process of transformation, after ten years of being the nurse-wife of a syphilitic, María Ríos Cárdenas became a famous feminist during her divorce. This history of subjectivization not only explains how an individual confronted the public health policies of the Porfiriato and the post revolution, but also establishes connections between changes in a personal life and the transformations of public life in Mexico.

Key words: procedural subjectivization; syphilis; hygienism; divorce; feminism.

Fecha de recepción: 30 de marzo de 2018 Fecha de aceptación: 14 de febrero de 2019

Es sta es la historia de un enfermo de sífilis en la ciudad de México cuya vida adulta la vivió en el tránsito de la moderada política higienista del porfiriato a la más agresiva de la posrevolución, cuando en los años veinte sucedieron las campañas antivenéreas más radicales en la historia de la salud pública de México. Lo relevante del caso no es sólo porque Rafael Montes de Oca (1863-ca. 1930), nuestro personaje central, estuvo enfermo de sífilis por casi 30 años, sino porque además fue el marido de una de las feministas más connotadas de la época: María Ríos Cárdenas, fundadora y directora de la revista Mujer. Periódico Independiente para la Elevación Moral e Intelectual de la Mujer (publicado entre 1926 y 1929). Aunque no conocemos apuntes ni diarios personales de Rafael que probablemente nos permitirían constatar los interminables sufrimientos que padeció con una enfermedad tan prolongada como devastadora moral y físicamente, sí tuvimos acceso a su juicio de divorcio entre 1928 y 1930; sus distintos documentos notariales y testamentarios de entre 1922 y 1928; la prensa de la época, y múltiples publicaciones de María Ríos Cárdenas, y la ficha curricular de esta, en los expedientes escolares de 
1918 a 1956 de la la Universidad Nacional. ${ }^{1}$ A través de todas estas fuentes pudimos ir conociendo, parcialmente, cada una de las etapas de su doloroso padecer y de cómo logró reconstruir su persona y, sobre todo, proponer una subjetivación reivindicativa no solamente en oposición y confrontación al agresivo discurso médico y político sino, incluso, ir más allá y tratar de redefinir su identidad según la explicación del paradigma estético guattariano.

Esta historia del proceso de subjetivación de Rafael Montes de Oca se analizará a partir de las teorías de las tecnologías del yo de Michel Foucault y el paradigma estético de Felix Guattari. ${ }^{2}$ Son varios círculos explicativos que se irán ampliando, en el centro está el conocimiento médico de finales del siglo xIX y principios del xx cuyo nuevo paradigma bacteriológico cambió por completo la concepción de una de las enfermedades venéreas más temidas a lo largo de los siglos: la sífilis. El siguiente círculo se compondrá de las agresivas campañas antivenéreas de principios del siglo xx, desarrolladas en el contexto de la política de salud pública posrevolucionaria llamada "dictadura sanitaria" -categoría utilizada por la prensa de la época-, y que no sólo fueron invasivas de la vida privada de las personas, sino que estigmatizaron a los sifilíticos como la peor decadencia de la civilización. ${ }^{3}$ El tercer y último círculo, que abarca a los otros dos, se centrará en el cambiante proceso de subjetivación de Rafael Montes de Oca quien, a partir del diagnóstico de sífilis que contrajo a principios de siglo, desarrolló distintas tecnologías del yo en las que buscó transformar la identidad de un "sifilítico degenerado" que le impuso la política higienista en varios procesos del cuidado de sí mismo y que concluyeron en su propio paradigma estético. Entonces los círculos con-

${ }^{1}$ Agradezco la ayuda de Roberto Beristáin Rocha, Lucila López de la Vega y Karen Durán en la búsqueda de la información.

${ }^{2}$ Las tecnologías del yo en la teoría de Foucault (2008, p. 48) significan una amplia gama de acciones que tienen que ver con la reflexión acerca de los modos de vida, las elecciones de existencia, el modo de regular la conducta y fijarse fines y medios. Lo que permite a los individuos efectuar por cuenta propia o con la ayuda de otros, cierto número de operaciones sobre su cuerpo y su alma, pensamientos, conductas, o cualquier forma del ser, obteniendo así una transformación de sí mismos con el fin de alcanzar cierto estado de felicidad, pureza, sabiduría o inmortalidad. Lo que Guattari (1996) define como "Nuevo paradigma estético" es el "caosmosis", es decir, una fuerza ético-estética que articula la potencialidad creativa con una finitud sensible y que puede ser aplicado al proceso creativo de nuevas formas y modalidades (p. 112).

3 "en nombre de la salud pública [el Departamento de Salubridad] se juzga autorizado para intervenir en lo más íntimo de la vida privada". En "El matrimonio y la salud. La peligrosa dictadura sanitaria”, sección Editorial, El Universal. El Gran Diario de México, domingo 6 de junio de 1926 , pp. 1 y 6. 
céntricos coinciden: los complejos saberes de la medicina bacteriológica del porfiriato; las sofisticadas estructuras de poder de la dictadura sanitaria, las campañas antivenéreas de la posrevolución y la compleja experiencia vital de Rafael. Se trata de contraponer las formas de gubernamentalidad higienistas de la época y las tecnologías de dominación que objetivaron los cuerpos de los sifilíticos como causantes del desorden social, la historia de la subjetivación reivindicativa de Rafael, cuyo caso particular demuestra la poca eficacia de los mecanismos de control antivenéreo de esos años.

Rafael contrajo sífilis en los primeros años del cambio de siglo, cuando contaba con casi 40 años de edad y desde entonces se fue planteando distintas disyuntivas de ¿qué hacer de sí mismo?, y ¿qué trabajo llevar a cabo sobre sí mismo? Y en la búsqueda de respuestas se fue modificando y construyendo nuevos mecanismos de autoafirmación. A pesar de la sífilis, o bien gracias a la sífilis, Rafael pudo aplicar distintas tecnologías del yo y entender reflexivamente su dolida alma, resignificando su identidad y su propio cuidado (Foucault, 2008, p. 58). En este texto no buscamos explicar la historia de la patología o la profilaxis de la sífilis sino la experiencia subjetiva, personal y única de un sifilítico. Dado que nos adentraremos en la vida privada e íntima de Rafael con información muy valiosa, pero con lagunas en algunos aspectos, la historia será integrada con las "posibilidades históricas" en el sentido propuesto por Carlo Ginzburg (2010, pp. 433-465), que se refieren a imaginaciones históricas sólidamente ancladas en las voces del pasado, gracias a que se profundiza en la investigación y en su contexto, entonces, se plantean posibilidades verosímiles.

\section{EL JOVEN RAFAEL IGNORA LA DISCRETA CAMPAÑA ANTIVENÉREA}

La primera etapa del proceso de subjetivación se desarrolla durante la juventud de Rafael Montes de Oca, quien nació en Jalapa, Veracruz, en 1863, de cuyos padres probablemente heredó propiedades, o bien, construyó su patrimonio mediante negocios exitosos, acumulando riquezas; lo que si es un hecho, es que decidió permanecer soltero durante muchas décadas, a pesar de haber procreado un hijo natural. ${ }^{4}$ En algún momento de su vida se trasladó a

\footnotetext{
${ }^{4}$ En la época era frecuente que varones de los grupos acomodados optaran por permanecer solteros hasta edades muy avanzadas y mayores a los 40 años (García Peña, 2016). Según las
} 
la ciudad de México y durante el cambio de siglo contrajo la enfermedad de la sífilis. ${ }^{5}$ En 1914 el discurso del médico Diego Carbonell en la Escuela de Medicina consideraba que los jóvenes infectados de sífilis habían tenido una vida mundana y vigorosa, por lo que su contagio era producto de haber bebido en las fuentes del amor impuro (Estrada, 2007, p. 46). Así que, según el contexto cultural de la época, muy probablemente Rafael, después de entregarse a los brazos de las meretrices y el comercio sexual, terminó por contagiarse con la bacteria llamada Spirochaeta pallida, causante de la sífilis. ${ }^{6}$

En esos años Rafael, posiblemente, se reconoció en sus actos sexuales y placeres que vivió con meretrices quienes satisfacían sus deseos, a pesar de todo el discurso moralista de la época. Era un empresario con fortuna y propiedades, prestamista de compañías como el Palacio de Hierro y el Banco de Francia en México, con bienes inmuebles en las colonias San Rafael, San Ángel y la Roma y propietario de una industria de plumaje; así que sus actividades económicas lo llevaron siempre a buscar el negocio provechoso y el oneroso préstamo hipotecario con intereses anuales superiores al 18 por ciento. ${ }^{7}$

En su juicio de divorcio se señala que Rafael Montes de Oca contrajo la sífilis entre 1900 y $1905^{8}$-es muy probable que la fecha exacta de su contagio ni él mismo la supiera, ya que históricamente la sífilis ha sido considerada

fuentes notariales, en marzo de 1926 Rafael reconoció a su hijo natural y en octubre del mismo año lo integró a su testamento. Notario 40. Ramón Cosío González. Vol. 59, 20 de octubre de 1926, f. 154. Escritura 2615. Testamento Rafael Montes de Oca. Archivo Histórico de Notarías Ciudad de México (en adelante AHNCM), México.

${ }^{5}$ Información del juicio de divorcio de Rafael Montes de Oca. Fondo Tribunal Superior de Justicia del Distrito Federal. Sección Siglo xx. Juicios Civiles. Juzgado 9 de lo Civil. Núm. de Registro 362. Actor, Ríos Cárdenas de Montes de Oca, María. Demandado Rafael Montes de Oca. Ordinario Civil. Divorcio Necesario. Juez Lic. Roberto Olagaray. Inició 23 de abril de 1928 finalizó 15 de enero de 1930. Exp. 399734, 113 fojas, caja 2193 (4 cuadernillos). Archivo General de la Nación (En adelante TSJDF. Cárdenas. 1928. Exp. 399734. AGN), México.

${ }^{6}$ En un primer momento cuando la espiroqueta de la bacteria de la sífilis fue descubierta por los médicos Hoffmann y Schaudinn en 1905 se le llamó spirochaeta pallida, posteriormente se le denominó Treponema pallidum (Turnes, 2007, p. 15).

${ }^{7}$ Se encontraron quince documentos en el Archivo Histórico de Notarías de la Ciudad de México realizados por Rafael Montes de Oca entre 1920 y 1928. Los documentos específicos a intereses hipotecarios son los siguientes: Notario 56. Antonio Ferriz. Vol. 26, 21 de agosto de 1922, fojas 118-119. Escritura 2682. Cancelación parcial. El Señor Rafael Montes de Oca al Señor José F. Moreno; Vol. 25, 13 de abril de 1923, fojas 282. Escritura 2819. Cancelación parcial. El Señor Rafael Montes de Oca al Señor Manuel Martínez; Vol. 28, 21 de mayo de 1923, fojas 6-8. Escritura 2840. Poder especial amplio. El Señor Rafael Montes de Oca al Señor Hipólito Signoret.

8 TSJDF. Cárdenas. 1928. Exp. 399734. AGN, México. 
una enfermedad "insidiosa" que sabe ocultarse y que en sus inicios con frecuencia pasa inadvertida- (Turnes, 2007, p. 14). ${ }^{9}$ De cualquier manera, Rafael se mantuvo soltero hasta los 55 años, no sabemos si por amor a la libertad o porque ya estaba enfermo y no se atrevía a contraer matrimonio, sabiendo toda la carga moral con la que se condenaba a los sifilíticos y se les impedía contraer nupcias (Estrada, 2007, p. 45). En 1900, el doctor Porfirio Parra definió a la sífilis como la enfermedad más destructora, repugnante y cruel que afligía a la humanidad, por lo que se insistía en la "castidad higiénica". ${ }^{10} \mathrm{La}$ máxima que repetían los galenos era: "A menor número de coitos, menores probabilidades de inoculación” (Lavalle, 1911, p. 57).

No obstante el discurso moralista-higiénico, en las postrimerías del porfiriato las campañas antivenéreas todavía eran parcialmente silenciosas y se centraban en la reglamentación y la persecución de la prostitución y la educación del público en general. En particular la existencia de hombres infectados de sífilis se escondía en la difusa y polémica bruma del secreto médico, lo que significó una escasa persecución del hombre sifilítico (Natividad, 2016, p. 96).

Por lo que en el contexto de la última época del higienismo moderado del porfiriato Rafael vivió su primera etapa de sífilis: en su cuerpo seguramente sufrió lo que la medicina de la época llamaba la "aparición del chancro después del coito infectante" (González, 1906, p. 447). Sin embargo, para la población en general era en realidad poca cosa: una llaguita que acompañaba alguna glándula cercana. El médico Suárez (1917) decía que "en numerosos casos los enfermos lo consideran como un simple grano, como una grieta, una escoriación insignificante, que a veces pasa inadvertida" (p. 747).

Según la sintomatología de la enfermedad en la época, después de tres meses de la primera manifestación, Rafael, al igual que todos los contagiados que no se atendieron oportunamente, pasaron a la segunda etapa de la sífilis o periodo secundario. Algunos de los síntomas que manifestaban los infectados eran: erupciones cutáneas principalmente en boca y genitales, dolores de cabeza y en articulaciones y huesos, además de algunas neuralgias y perturbaciones nerviosas. De cualquier manera, no eran tan graves para los enfermos

9 En su primera etapa la sífilis se contagia por el contacto con la membrana mucosa durante el sexo oral, vaginal o anal, pero también se puede contagiar por exposición a lesiones de los famosos bubones o chancros de la etapa secundaria (Leitner, Körte, Edo y Braga, 2007, pp. 6 y ss.)

${ }^{10}$ Conferencia sobre profilaxis de la sífilis en Bruselas y se nombran como representantes de México al doctor Porfirio Parra y al licenciado Jesús Zenil. Instrucción Pública y Bellas Artes. Caja 272. Exp. 4, fs. 34. AgN, México. 
de aquellos años pues todavía eran curables. Los galenos decían que lo más importante de esa segunda etapa era el contagio al tercero (Suárez, 1917, p. 742).

Durante todos esos primeros años de su enfermedad, posiblemente Rafael abrigó las esperanzas de sanar y buscó incansablemente la ayuda de galenos. Pero, ¿cómo experimentó toda esta etapa de su vida?, ¿acaso manifestó una constante lamentación por desobedecer el mandato y haber violentado la norma del "no" a los amores lascivos?, o tal vez ¿tuvo periodos muy prologados de latencia de la enfermedad, permitiéndole llevar una vida aparentemente normal e ignorar la esporádica sintomatología de su cuerpo? De cualquier manera, la enfermedad siguió avanzando y Rafael tuvo que buscar nuevas opciones.

\section{ALIFAFES Y DOLAMES LE LLAMARON AL ORDEN, Y ENTONCES ACORDÓ CASARSE ${ }^{11}$}

Con el cambio de siglo, Rafael fue testigo de las últimas etapas de la tradicional política higiénica y vivió en carne propia los primeros pasos de la moderna y agresiva política de salud pública. Uno de los más importantes modos de objetivación de este nuevo saber médico y político fue el Instituto Bacteriológico Nacional creado en 1905 y que permitió difundir ampliamente el nuevo paradigma médico de la bacteriología y la "Teoría del germen" (Carrillo, 2002, pp. 17, 21; Vera Bolaños y Pimienta Lastra, 2001). ${ }^{12}$

Los inicios de la bacteriología fueron muy importantes para la historia de la sífilis, pues su detección en México se comenzó a realizar de una manera mucho más precisa y, desde fechas muy tempranas como 1905 y 1906, se utilizaron los estudios de laboratorio médico de microbiología, que emplearon el procedimiento del suero-reacción biológica de Wasserman para detectar la bacteria específica de la sífilis. A partir de esos años, el diagnóstico ya no sólo dependía del criterio subjetivo y clínico del médico, sino también de los análisis de laboratorio (Otero, 1910, p. 163; Raso, 1919, p. 19).

Al tiempo del cambio de paradigma con la bacteriología, las campañas antisifilíticas como las de 1908 y la de 1918 fueron cada vez más agresivas, al

${ }^{11}$ Cita del cuento "Feminista" de Emilia Pardo Bazán (1909), Díptico. Cuentos. El relato narra la historia de un hombre desahuciado, quien debido a los achaques y malestares de su enfermedad decide casarse para tener una "enfermerita" que lo cuide (pp. 49-51).

${ }^{12}$ Para profundizar en el paradigma de la bacteriología y la historia de la etiología de las enfermedades bacterianas con los postulados de Robert Koch, véase Turnes (2007, pp. 20 y ss.). 
definir a la sífilis como una verdadera plaga social y peligro colectivo. Se trató de imponer una vigilancia médica forzosa para todos los sifilíticos y la práctica de que ningún paciente podía negarse a recibir atención médica, pues de lo contrario sería denunciado ante las autoridades sanitarias y las corporaciones de vigilancia del Consejo de Salubridad como la Sociedad Mexicana Sanitaria y Moral de Profilaxis de las Enfermedades Venéreas (Suárez, 1917, p. 747). También se implementaron nuevas estrategias como la de reformar los códigos tanto civiles como sanitarios y publicar en la prensa boletines de salud; establecer por primera vez la presentación de certificados médicos de buena salud como requisito, no obligatorio, para contraer matrimonio (Carrillo, 2010, pp. 65-68). Todas estas acciones terminaron con la vieja tradición del secreto médico de mantener la secrecía para proteger la vida privada de los varones infectados; y en las modernas clínicas o departamentos antivenéreos de los nosocomios como el Hospital General o el Militar lo que menos importó fue la discreción y el ocultamiento.

Durante esos años de las campañas antisifilíticas, cambiamos la explicación según el círculo concéntrico y revisamos la experiencia vital de Rafael, ¿cómo construyó alivio para su cuerpo enfermo y logró enfrentar el rechazo social y cultural de las campañas?, ¿qué hizo consigo mismo para seguir viviendo? Es un hecho que no se derrotó, sino que buscó nuevos sentidos a su vida y cuidó de sí mismo a través de un matrimonio concertado con una humilde enfermera.

Hacia mediados de la segunda década del siglo xx la sífilis de Rafael avanzó hacia la tercera etapa, la más agresiva y dolorosa de todas. En ese momento, ya no funcionaban las curaciones que se hacía en su domicilio particular, por lo que a partir de 1917 -según se refiere en el juicio de divorcio-, comenzó a acudir a las instalaciones del Hospital Médico Militar de Instrucción, en particular a la Clínica de Enfermedades Venero-Sifilítica creada en 1892 y que albergaba la Escuela Médico Militar, especializada en la práctica quirúrgica y el tratamiento de la sífilis (Moreno Guzmán, 2016, 2017). No deja de ser atípico que un ricachón del nivel de Montes de Oca asistiera a la institución del Hospital Militar, ya que en esos años las personas de cierto poder adquisitivo no atendían sus enfermedades en los hospitales, normalmente se trataban en la comodidad de sus domicilios particulares. Además, hay que considerar que en dicho nosocomio se atendían a los militares infectados de sífilis que, según las investigaciones de Carrillo (2010, p. 729) representaban 
una verdadera crisis epidemiológica entre los miembros del cuerpo castrense hasta llegar a representar la tercera parte de los efectivos.

Aunque desconocemos las razones por las cuales comenzó a curarse en el Hospital Militar, es un hecho que en dicho nosocomio recibió los servicios médicos del doctor Alfonso Jiménez O’Farril -según se refiere en el juicio de divorcio-, facultativo que lo siguió tratando durante muchos años, hasta 1928. La presencia del doctor O'Farril en la vida de Rafael fue muy importante no sólo porque lo atendió con destreza, sino porque también tuvo como enfermera asistente a María Ríos Cárdenas, así que dicho médico fungió como una especie de Celestino que presentó al sifilítico con la enfermera. ${ }^{13}$

María Ríos Cárdenas era una provinciana que desde muy joven llegó a la ciudad de México, y con muchos esfuerzos logró formarse como enfermera en el Hospital General entre 1914 y 1918. Cuando por fin consiguió su título de primer nivel en marzo de 1918 fue mandada en comisión a la Clínica de Enfermedades Venero-Sifilítica del Hospital Militar. Para María fue una verdadera oportunidad su traslado a dicho nosocomio pues duplicó su salario de 1.50 pesos diarios que ganaba en el Hospital General a tres pesos en el Militar. $^{14}$ Vale la pena señalar que, en la época, la profesión de las enfermeras era mal vista y se consideraba que realizaban labores similares a las de sirvientas (Torres Barrea y Zambrano-Lizárraga, 2010; Villeda García, Rodríguez-González y Córdova-Ávila, 2010), por lo que la vida para María no fue nada fácil. Pero Ríos Cárdenas sólo duró en dicho puesto menos de tres meses, pues el 18 de junio del mismo año presentó su renuncia y diez días después contrajo matrimonio civil con Rafael. Fue una boda sencilla en la populosa colonia Guerrero, donde vivía María Ríos, incluso los testigos fueron sus vecinos circunstanciales, pues según información del acta de matrimonio, dos de ellos vivían en una calle aledaña y pernoctaban en los dormitorios públicos del Estanco de Mujeres. ${ }^{15}$

${ }^{13}$ Durante el juicio de divorcio el médico Jiménez O’Farril presentó un peritaje el 3 de julio de 1928 en el que señaló que conoció a María Ríos como enfermera en la Sala de Venero Sífilis del Hospital Militar y que después, ya como esposa de Rafael Montes de Oca, le mandó aplicar las inyecciones de Neosalvarsán. TSJDF. Cárdenas. 1928. Exp. 399734, fs. 1734. AGN, México.

${ }^{14}$ Osornio, Enrique. General de Brigada. Médico Cirujano, Jefe del Departamento del Cuerpo Médico Militar de la Secretaría de Guerra y Marina. Relación de los servicios prestados en el cuerpo de Médico Militar por la enfermera titulada María Ríos Cárdenas. 23 de junio de 1918. Secretaría de Guerra y Marina. TSJDF. Cárdenas. 1928. Exp. 399734. AGN, México.

${ }_{15}$ TSJDF. Cárdenas. 1928. Exp. 399734, fs. 1-2. AGN, México. Para profundizar en el tema de los dormitorios públicos en la Ciudad de México a principios del siglo xx, véase Barbosa (2003). 
Diez años después de este matrimonio, la fama pública de María Ríos como una feminista destacada provocó que un periodista de La Prensa publicara una versión romántica de cómo sucedió la boda, en el texto que subtituló "Dejó su profesión por el hogar y éste fue un calvario":

Allá, cuando las huestes constitucionalistas eran dueñas y señoras de la metrópoli, se iniciaron los amores, por demás románticos, de una enfermera del Hospital Militar y un acaudalado señor que rebozaba de juventud y energías. Este se prendó locamente de aquella muchacha que salía diariamente del hospital, ubicado en el Cacahuatal y todas las compañeras de ella supieron de aquellos amores que hace 11 años terminaron en el altar y en las oficinas del Juez del registro Civil, quien sancionó el enlace en el domicilio de ella, 181 de las calles de la Mosqueta. La señorita María Ríos Cárdenas y el señor Rafael Montes de Oca, eran esposos ante la ley, a las siete de la noche del 29 de junio de $1918 .{ }^{16}$

Aunque el periódico La Prensa quiso dibujar una relación romántica en la que la joven provinciana se dejó deslumbrar por el ricachón capitalino, lo que muy probablemente sucedió fue un arreglo material entre el acaudalado Montes de Oca y la enfermera María Ríos Cárdenas. La revisión del juicio de divorcio y los archivos Histórico de Notarías de la Ciudad de México y el Histórico de la UNAM nos corroboran la hipótesis de que el matrimonio fue un acuerdo monetario en el que la enfermera especializada en cuidados de sifilíticos se comprometía a cuidar al enfermo a cambio de importantes beneficios como el traslado de dominio de ciertas propiedades; el traspaso a su nombre de la propiedad de una industria de plumaje; y la posibilidad de estudiar una carrera profesional en la Universidad de México. Después de su matrimonio en junio de 1918, a los dos meses, en agosto, María comenzó la carrera de Profesora de Lengua y Literatura Castellana en la Escuela de Altos Estudios de la Universidad de México, misma que concluyó en 1920 y luego realizó sus primeros ensayos como periodista. ${ }^{17}$

16 "Una nueva tragedia del matrimonio", La Prensa. Diario Ilustrado de la Mañana, t. 1, núm. 253, viernes 10 de mayo de 1929.

${ }^{17}$ Los documentos notariales en los que Rafael transfiere propiedades a María, a través de terceros, ya que el derecho civil prohibía ese tipo de transacciones entre esposos, son los siguientes: Notario 39. Nicolás Tortolero y Vallejo. Vol. 174, 25 de septiembre de 1924, fs. 5663. Escritura 10780. Compraventa. Emilia Águila viuda de Huerta, Rafael Montes de Oca y María Ríos Cárdenas de Montes de Oca; Notaría 40. Ramón Cosío González. Vol. 56, 9 de 
Cuando Rafael y María se casaron en 1918 él tenía 55 años y ella 27, y lo celebraron bajo los lineamientos que establecían los artículos $1^{\mathrm{o}}$ y 17 de la moderna Ley sobre Relaciones Familiares decretada por Venustiano Carranza en 1917, entre cuyos requisitos estaba el certificado médico de buena salud, que más bien era facultativo y no obligatorio, pues sólo se fundamentaba en la "protesta de decir verdad de que los pretendientes no tienen impedimento para celebrar matrimonio" (Carranza, 1917, p. 9). Aunque en la campaña antisifilítica de 1918 se señalaba que el Consejo Superior de Salubridad revisaría que los jueces del registro civil respetaran el mandato de exigir a los solicitantes de matrimonio "las pruebas fehacientes de estar indemnes de la avería". ${ }^{18}$

De cualquier manera, Rafael presentó un falso certificado médico de buena salud emitido por el médico Pérez Amador, practicante del Hospital Militar, quien por cierto también fue testigo de su boda y era vecino de María. Ya fuese por el desorden que había dejado la fase más combativa de la revolución mexicana, o porque apenas comenzaba a operar el Departamento de Salubridad Pública, pero lo cierto es que los certificados médicos prenupciales apenas si se usaban. ${ }^{19}$ Es importante resaltar que sólo se presentó el certificado médico de Rafael Montes, pues al parecer el de María Ríos no fue necesario. En la condena social contra la sífilis para el ámbito familiar, la carga moral recaía básicamente sobre el varón, pues se sobreentendía que una novia llegaba virgen al matrimonio por lo que era menos probable que padeciera alguna enfermedad de transmisión sexual.

Más allá de considerar al certificado médico de buena salud de Rafael como un documento falso o un acto de corrupción emitido por un practicante médico y amigo personal de los novios, es pertinente considerarlo como

septiembre de 1926, fs. 124-126. Escritura 2557. Cesión Rafael Montes de Oca e Ygnacio Ocampo y Amezcua; Vol. 57, 9 de septiembre de 1926, fs. 117-120. Escritura 2558. Cesión Ygnacio Ocampo y Amezcua a María Ríos Cárdenas de Montes de Oca. AHNCM, México. Los datos sobre la formación profesional de María en: 1908-1956. Ríos Cárdenas, María. Fondo Historia Escolar. Ramo Instituto de Investigaciones sobre la Universidad y la Educación. Exp. 19/221. Archivo Histórico de la unam (en adelante AhUnam), México.

${ }^{18}$ Campaña contra la propagación de la sífilis. Archivo Histórico de la Secretaría de Relaciones Exteriores (en adelante AHSRE). Disposiciones generales para evitar la propagación de la avería. Se lleva por acuerdo presidencial al Consejo de Ministerios. 1918. Clasf. 18-1-131, fs. 6-8. AGN, México.

${ }^{19}$ Casi diez años después de la creación del Departamento de Salubridad, en 1926 el periodista Pablo de Góngora señalaba la poca práctica del certificado médico con esta frase punzante: "No hay que criticar la intención, sino la inocencia de su práctica posible" en "Los matrimonios salubres”, El Universal. El Gran Diario de México, domingo 6 de junio de 1926. 
la abierta confrontación que realizó un sifilítico en contra de la creciente y agresiva política antivenérea del gobierno, pues logró poner en entredicho el supuesto valor objetivo del documento. Fue un verdadero acto de autoafirmación en su subjetivación procesual. Además, el matrimonio del sifilítico con la enfermera no fue para cumplir los objetivos que establecía el Estado de difundir una procreación sana cuyos hijos fuertes y saludables mejorarían la raza, sino para fines personales muy distintos.

En esta lógica, el acto de afirmación que realizó Rafael fue casarse aun siendo sifilítico, construyéndose al mismo tiempo un futuro para gobernarse por sí mismo. De alguna manera, realizó el acto simbólico de la posesión de una mujer, pero no para tener sexo con ella o buscar la procreación, sino que se buscó su propia enfermera especializada para que lo cuidara en forma privada y ya no tener que ir a la sala de sifilíticos del Hospital Militar de Instrucción y exponerse a las miradas inquisitivas de los demás. Rafael logró construir un cuidado intermedio entre el brindado por los especialistas hospitalarios, pero lejanos emocionalmente y el familiar, cercano emocionalmente pero poco especializado. Con su esposa-enfermera logró conciliar ambos cuidados, el emocional y el de una profesional especializada en cuidados venéreos. El cuento "feminista" de la famosa escritora española Emilia Pardo, de 1908, cuya cita incluimos en el título del subtema, nos demuestra que era una práctica reconocida en la cultura hispanoamericana el que los hombres ricos y enfermos buscaran una "esposa enfermerita" para que los cuidara (Pardo, 1909, pp. 49-51).

A cambio de los esmerados y profesionales servicios de enfermería que prestaba, María comenzó a vivir como una señora propietaria, algo que su raquítico sueldo de enfermera nunca le hubiera permitido. Pero el matrimonio no sólo fue en beneficio de María, sino que también Rafael comenzó a cambiar sus ocupaciones y dedicó mucho más tiempo al cuidado de sí mismo. Si en su acta de matrimonio de 1918 Rafael firmó como "industrial" porque en aquella época él administraba su empresa de plumaje, después de 1920 en sus documentos notariales comenzó a firmar solamente como "comerciante" y María pasó a ser la propietaria de la empresa de plumaje. ${ }^{20}$ Así que un segundo acto de cuidado de sí que realizó Rafael fue dejar el desgaste cotidiano de

${ }^{20}$ Notario 39. Nicolás Tortolero y Vallejo. Vol. 174, 25 de septiembre de 1924, fs. 56-63. Escritura 10780. Compraventa. Emilia Águila viuda de Huerta, Rafael Montes de Oca y María Ríos Cárdenas de Montes de Oca. AHNcm, México. 
dirigir una empresa, y entre 1920 y 1926 se dedicó sólo a actividades de prestamista que seguramente le dejaron más tiempo para redefinir su identidad desde un mayor cuidado de sí mismo.

Durante los años de matrimonio, de 1918 a 1927, la sífilis terciaria de Rafael entró a su peor etapa. Su médico de cabecera, el doctor Alfonso Jiménez O'Farril -quien emitió un certificado médico durante su juicio de divorcio en 1928-, describió con un lenguaje frío y descarnado la precisa historia sifilítica de Rafael Montes de Oca,

El médico cirujano que suscribe, legalmente autorizado para ejercer su profesión, CERTIFICA: que hace varios años (unos seis) [1922] presté mis servicios profesionales al señor RAFAel MONTES DE OCA en su domicilio de la Plaza de Santiago. En dicha época el señor Montes de Oca, presentaba ya signos y síntomas característicos avanzados y inconfundibles de una infección luética en su tercer periodo (Sífilis cerebro espinal) padecimiento cuyo principio databa por lo menos de veinte años [1902], más o menos. (Reacción positiva de Wasserman. Reacciones positivas en líquido cefalo raquideo, etc. Abolición de reflejos) Es decir, presentaban el último periodo de su padecimiento. Fue sujetado a inyecciones intrarraquídeas de suero mercurializado de caballo, aplicaciones de Neo Salvarsan en dosis progresivas e inyecciones de sales de bismuto (Quimby). Estas últimas inyecciones fueron aplicadas por su esposa a quien recomendé lo hicera por haberla conocido como enfermera de la Sala de Venero Sífilis del Hospital Militar de Instrucción, Practicante de dicho Hospital. [Dr. Alfonso Jiménez O’Farril]..$^{21}$

De un plumazo, el doctor O'Farril le impuso a Rafael el dictamen de estar viviendo el último periodo de su padecimiento y de su vida. Y tal vez no era para menos, pues la etapa terciaria de la sífilis era descrita con esta lastimera sintomatología en 1917:

La sífilis cerebro medular con ataxia locomotriz ataca las funciones cerebrales y provoca: diversas parálisis, hemiplejia, paraplejia; perturbaciones de los sentidos, perturbaciones intelectuales como delirio, estupidez, enajenación, demencia, etc. Un sinfín de degeneraciones cuyo fin último es la muerte. Si el

${ }^{21}$ TSJDF. Cárdenas. 1928. Exp. 399734. AGN, México. 
paciente llega a sobrevivir queda con invalidaciones permanentes y definitivas, parálisis y decadencia intelectual. (Suárez, 1917, pp. 749-750).

Según las descripciones médicas de la época, las inyecciones intrarraquídeas de suero de mercurializado de caballo y el arsenical de Neo Salvarsán que le aplicaban a Rafael eran muy dolorosas, ${ }^{22}$ y los efectos de dichos medicamentos eran incluso peores que los malestares de la enfermedad debido a su gran toxicidad, provocando abscesos, encefalitis, neuritis, miopía, anemia, toxicodermias, estomatitis, alteraciones de riñones e hígado, alteraciones en el sistema nervioso y los sentidos, anemia, fiebres y trastornos en la nutrición, entre muchos otros efectos. ${ }^{23}$ Por lo que podemos imaginar los continuos dolores con los que vivió Montes de Oca esos años de su vida.

Metafóricamente hablando, a diferencia de su juventud, cuando, probablemente, Rafael se entregó al placer y se contagió de sífilis; ahora en su madurez, con una sífilis terciaria y agresivos tratamientos médicos que lo imposibilitaban por mucho tiempo, tuvo que renunciar al placer sexual, pero fue una renuncia parcial al mundo y a él mismo, "una especie de muerte diaria", como la llama Foucault (2008, p. 166).

Así que, según el modelo de objetivación del régimen médico bacteriológico, Rafael ya no tenía casi ninguna posibilidad de seguir viviendo, pero en sentido contrario a la derrota del discurso científico, él no se entregó a la desmoralización de "ya no hay nada que hacer, más que esperar la muerte", sino que cuando la sífilis atrofió cada vez más y más su cuerpo, Rafael también acentuó el cuidado de sí mismo en los términos foucaultianos y logró reinventarse una vez más.

\section{EL CLÍMAX DE LA SUBJETIVACIÓN: EL ARTISTA}

El año de 1926 fue de una coyuntura fundamental no sólo en la vida de Rafael Montes de Oca sino también en la política de la salud pública del Estado mexicano cuando se instauró plenamente lo que la prensa de la época llamó

22 TSJDF. Cárdenas. 1928. Exp. 399734. AGN, México.

23 Para profundizar sobre los efectos nocivos de los tratamientos antisifilíticos en el pasado, véase Leitner, Körte, Edo y Braga (2007). 
"la dictadura sanitaria" y se estableció una dura persecución en contra de los sifilíticos a través de las campañas antivenéreas. Revisemos ambos procesos.

En el círculo explicativo del ámbito de la política de salud pública, los años veinte significaron un cambio radical en las acciones de los gobiernos posrevolucionarios porque se impuso "la dictadura sanitaria", entendida como una nueva forma de gubernamentalidad higienista que supuestamente enfrentaría agresivamente los problemas colectivos. La salud pública quedó bajo el dominio absoluto de la eugenesia médica que dio facultades ilimitadas a la Dirección de Salubridad Pública en actividades como las inspecciones médicas generalizadas, los servicios de higiene escolar y las múltiples campañas antivenéreas (Carrillo, 2002, p. 24).

Las nuevas tecnologías de dominación trataron de objetivar los cuerpos de los sifilíticos como los causantes de la decadencia y la degeneración, por lo que se crearon discursos eugenésicos para alejarlos del matrimonio, argumentando una relación directa entre raza y patria. El Estado debía controlar en todas sus manifestaciones la vida reproductiva de las personas y decidir si estaban o no aptos para contraer matrimonio, así que ya no era posible dejar al azar las uniones amorosas, pues lo más importante era propagar una cultura de individuos sanos (Natividad, 2016, p. 91). La norma por excelencia de este cambio discursivo fue el nuevo "Código sanitario" de 1926 que en sus artículos 129 y 131 no sólo insistió en la importancia de tener relaciones sexuales exclusivas en el matrimonio, sino que también impuso la persecución del secreto médico y la obligatoriedad del certificado médico de buena salud para contraer matrimonio. ${ }^{24}$

En lo que respecta al secreto médico se intentó imponer un control estricto sobre los médicos para que notificara a las autoridades del estado de salud de sus pacientes anotando nombre, apellido y domicilio, y si algún paciente abandonaba su tratamiento se debería informar al Departamento del Consejo Superior de Salubridad. ${ }^{25}$ La información sobre los peligros de la sífilis se difundió por todos los medios a través de pláticas, conferencias, exhibición de películas y carteles, así como llevada a todos los sectores de la sociedad como

24 “Código Sanitario de los Estados Unidos Mexicanos", en Diario Oficial. Órgano del Gobierno Constitucional de los Estados Unidos Mexicanos, martes 8 de junio de 1926, t. xxxvi, núm. 31, pp. 367-456.

${ }^{25}$ Campaña contra la propagación de la sífilis. AHSRE. Disposiciones generales para evitar la propagación de la avería. Se lleva por acuerdo presidencial al Consejo de Ministerios. 1918. Clasf. 18-1-131. AGN, México. 
cárceles, regimientos militares, escuelas, mercados, vía pública, centros populares, teatros y circos (Inauguración, 1927, pp. 162-174). En los cientos de folletos que se imprimieron se insistía en que ya el secreto médico resultaba "una moral inverosímil" que pretendía sacrificar inocentes para proteger culpables, era un prejuicio -decían los folletos- permitir entrar la sífilis al hogar argumentando decencia (Gastelum, 1926, pp. 386-390). Finalmente, el secreto médico perdió importancia en el diagnóstico y tratamiento de los enfermos varones.

Por lo que respecta al certificado médico de buena salud como requisito para el matrimonio se volvió absolutamente obligatorio, pues como señala el doctor Gastelum (1926) "ya no deberían existir matrimonios indeseables" (p. 27), así que tanto los jueces del registro civil como los sacerdotes de los cultos estaban obligados a exigir dichos certificados a los contrayentes, tanto hombres como mujeres. Además el certificado ya no era un simple juramento de decir la verdad por parte del médico o el contrayente, sino que debían presentarse los estudios de laboratorio de la reacción Wassermann u otra equivalente; es decir, implicaba el análisis de sangre serológico para corroborar que no se padeciera ninguna enfermedad venérea.

Esta práctica era difundida bajo el eslogan "sanar es eugeniezar", buscando crear hombres y mujeres aptos para las nuevas necesidades de la sociedad y libres de enfermedades hereditarias o venéreas, además de la promoción de una supuesta salud moral que con prácticas higiénicas de abstinencia los varones lograrían impedir el contagio (Natividad, 2016, p. 93). Las críticas de la prensa a esta nueva dictadura sanitaria no se hicieron esperar y en distintos editoriales de El Universal se insistía que el gobierno sólo estaba promoviendo una hipocresía social que aumentaría las inmoralidades pública y burocrática. Y en son de burla decía que dicha obsesión controladora era como vivir el viejo refrán: "Si quieres vivir sano, hazte viejo temprano." 26

En el círculo concéntrico de la experiencia vital de Rafael, en ese mismo año de 1926, y en un proceso totalmente opuesto a la dictadura sanitaria, vivió una fuerte crisis médica y sintió muy cercana la muerte, por lo que realizó cambios muy significativos en su vida que reflejaron un creciente cuidado de sí mismo. Cabe señalar que para esa fecha tenía 64 años, por lo que no cabe duda de que era un hombre muy resistente y que ni siquiera la devastadora sífilis logró arrancarle años a su longeva vida. Su edad estaba muy por encima

26 "El matrimonio y la salud. La peligrosa dictadura sanitaria. Los matrimonios y la ley sanitaria”, El Universal. El Gran Diario de México, domingo 6 de junio de 1926, pp. 1 y 6. 
de la esperanza de vida de la época que apenas si llegaba a los 40 años (Alba-Hernández, 1976, p. 33).

Uno de los cambios que Rafael realizó fue reconocer en marzo de 1926 a su único hijo natural, quien tenía más de 30 años y había formado un matrimonio y procreado cuatro hijos. Un semestre después, cuando continuó su crisis médica, cedió algunas de sus hipotecas a nombre de su esposa. Pocos días después redactó su primer testamento, nombrando a María Ríos como su única y universal heredera y albacea de sus bienes. ${ }^{27}$ Por razones inexplicables, tal vez por culpa moral o porque María asumió un comportamiento cada vez más interesado, un mes después modificó dicho testamento y decidió dividir su fortuna en dos partes iguales, la mitad para María y la otra para su hijo natural. ${ }^{28}$

Pero el cambio más importante que acentuó la subjetivación de Rafael fue que en 1926 dejó de firmar sus documentos notariales como "industrial" o "comerciante", por lo que podemos suponer que decidió alejarse de la actividad política o pública de la industria o el comercio y comenzó a usar la autodefinición de "artista", como para señalar que se estaba ocupando de sí mismo. ${ }^{29}$ Más allá de considerarlo como un simple añadido en sus firmas notariales, podemos proponer la hipótesis de que Rafael le dio un nuevo sentido a su vida, centrada ahora en su creación artística como escultor. Según el documento pericial presentado por el doctor Jiménez O'Farril durante el juicio de divorcio en el año de 1928, Rafael llevaba, por lo menos, seis años recibiendo el agresivo tratamiento de mercurio y arsénico. ${ }^{30}$ Él estaba cansado

${ }^{27}$ Notario 40. Ramón Cosío González. Vol. 158, 10 de septiembre de 1926, fs. 115-116. Escritura 2559. Testamento público abierto. Rafael Montes de Oca. AHNCM, México.

${ }^{28}$ Notario 40. Ramón Cosío González. Vol. 159, 20 de octubre de 1926, f. 154. Escritura 2615. Testamento público abierto. Rafael Montes de Oca. АнNCM, México.

${ }^{29}$ Rafael firmó como "artista" en los siguientes documentos: Notario 40. Ramón Cosío González. Vol. 56, 9 de septiembre de 1926, fs. 124-126. Escritura 2557. Cesión. Rafael Montes de Oca e Ygnacio Ocampo y Amezcua; Vol. 57, 9 de septiembre de 1926, fs. 117-120. Escritura 2558. Cesión Ygnacio Ocampo y Amezcua, María Ríos Cárdenas de Montes de Oca; Vol. 158, 10 de septiembre de 1926, fs. 115-116. Escritura 2559. Testamento público abierto. Rafael Montes de Oca; Vol. 59, 20 de octubre de 1926, f. 154. Escritura 2615. Testamento. Rafael Montes de Oca; Vol. 74, 9 de septiembre de 1926, fs. 81-82. Escritura 3644. Protesto. Juan Suárez Ramírez a Rafael Montes de Oca; Notario 40. Licenciado Álvaro Ysla adscrito encargado. Vol. 73, 9 de septiembre de 1926, fs. 136-138, Escritura 3698. Testamento y revocación Rafael Montes de Oca; Vol. 75, 28 de abril de 1928, fs. 115-118. Escritura 3710. Compraventa. Rafael Montes de Oca e Ygnacio Ocampo y Amezcua. AHNCM, México.

30 TSJDF. Cárdenas, 1928. Exp. 399734, fs. 1734, AGN, México. 
y necesitaba un nuevo sentido para su vida, así que el arte y los sentimientos que le provocaba pudieron llevarlo a crear una ruptura con sus viejas formas de ser; ya no se trataba de conquistar afuera una mejor posición económica, sino de comenzar a profundizar en su mundo interior. Así que Rafael se enfrentó a la disyuntiva de desingularizarse de la enfermedad y recomponer su corporeidad existencial en un ente creativo, en eso que Guattari (1996) llamó un "Nuevo paradigma estético" (pp. 121 y ss.). A través de dicho paradigma encauzó su creatividad procesual y logró alejarse, por momentos, de su dolido cuerpo. Señala Guattari (1996) que el arte, como ninguna otra actividad creativa, tiene la capacidad mutante de invención de coordenadas y de engrandecimiento de cualidades (p. 130).

El gran cariño que Rafael tuvo por su arte escultórico lo llevó a nombrar delicadamente las obras de arte que heredaba a su esposa-enfermera, con quien compartió sus experiencias de subjetivación en la enfermedad y también en la práctica de su expresión artística. El tránsito de los negocios al arte puede presumirse como una nueva manera de enfrentar 30 años de sífilis y reconstituir lo real con "afectos mutantes" de nuevas formas y modalidades, además de posibilitar la emergencia de una obra de arte. En cada una de las esculturas que realizó -de las que lamentablemente no pudimos conseguir ningún registro-también estuvo dando forma a nuevas modalidades de subjetivación procesual (Guattari, 1996, pp. 22, 124).

\section{EL FIN DE LA HISTORIA: RUPTURA EN EL DIVORCIO Y EMERGE LA FEMINISTA}

La parte final de la historia de las subjetivaciones de Rafael Montes de Oca está marcada por el retroceso de muchos de los logros que había conseguido hasta 1926, ya que entre 1927 y 1930 su nueva vida de artista se hundió en la decadencia; era un anciano de 68 años y su sífilis terciaria ya había afectado su sistema nervioso central provocándole una aguda ataxia, además de una creciente psicosis medular. ${ }^{31}$ Así que vivió tres experiencias simultáneas: la

${ }^{31}$ La ataxia es la progresiva pérdida del control muscular y de los movimientos voluntarios, que se desarrolla en la etapa terciaria de la sífilis, cuando la enfermedad invade el sistema nervioso central, provocando una neurosífilis y una creciente parálisis, además de una evolución demencial progresiva, combinando la excitación intelectual y accesos maniacos con estados depresivos. Véase Turnes (2007). 
vejez, el deterioro de su cuerpo debido a una devastadora enfermedad y una prolongada muerte.

Aunque no podemos probarlo plenamente, suponemos que la ruptura de la relación entre Rafael y María inició en el segundo semestre de 1926, según el contenido de los documentos notariales; el rompimiento total sucedió cuando María promovió la demanda del juicio de divorcio necesario en marzo de $1928 .{ }^{32}$ Con la información que poseemos la reconstrucción del proceso es la siguiente: en la biografía de María Ríos reconocemos que ella nunca estuvo enferma de sífilis, así que podemos suponer que no tuvo vida íntima con su esposo-paciente y sólo fue su esposa-enfermera, por lo que el matrimonio fue sólo una relación de camaradería y de beneficios mutuos, pero no de intimidad sexual. Pero esa relación de amistad comenzó a romperse cuando en 1926 Rafael redactó su testamento: en la versión de septiembre nombró a María su heredera universal, ${ }^{33}$ pero un mes después cambió de parecer y en la nueva redacción dividió en partes iguales sus bienes para María y su hijo natural. ${ }^{34}$ Dicho testamento de octubre incluyó una cláusula muy importante: Rafael señaló que todo su dinero en efectivo lo tenía depositado en un banco de Montreal a nombre suyo y de su esposa, por lo que podemos proponer la hipótesis de que María hizo uso de dicho capital y tan sólo dos meses después, en diciembre de 1926, pudo capitalizarse e iniciar el proyecto más ambicioso de su vida, la fundación de una importante revista que le permitió asumirse públicamente como una feminista de vanguardia y comprometida con las luchas más preclaras del feminismo mexicano, la revista Mujer. Periódico Independiente para la Elevación Moral e Intelectual de la Mujer, que se publicó del 12 de diciembre de 1926 al 12 de diciembre de 1929.

Ahora bien, las razones de la ruptura pueden ser las siguientes: la primera, para María no fue justo que después de diez años de cuidarlo pacientemente, Rafael hubiese incluido a un hijo natural en la repartición de sus bienes en la segunda versión del testamento. La segunda razón, después de conocer el segundo testamento y de usar el capital familiar en su beneficio, María actuó por su propio interés, así que se concentró en su revista y comenzó a descuidar a su esposo enfermo. Para Rafael no fue justo que María utili-

32 TsjDF. Cárdenas, 1928. Exp. 399734, f. 1734. AGN, México.

33 Notario 40. Ramón Cosío González. Vol. 158, 10 de septiembre de 1926, fs. 115-116. Escritura 2559. Testamento público abierto. Rafael Montes de Oca. AHNCM, México.

${ }^{34}$ Notario 40. Ramón Cosío González. Vol. 159, 20 de octubre de 1926, f. 154. Escritura 2615. Testamento público abierto. Rafael Montes de Oca. AнncM, México. 
zara el capital familiar en un proyecto feminista, por lo que su reacción desde el primer momento fue de desagrado y la tensión entre la pareja comenzó a crecer más y más.

Durante ese tiempo María se volvió más famosa y más "pública" en el sentido de desenvolverse en la esfera de las relaciones públicas, y la convivencia con su esposo sifilítico se fue deteriorando. Podemos tratar de entender el malestar de Rafael, pues a su ya de por sí dañada imagen pública de ser un sifilítico en fase terminal se sumó la de ser esposo de una feminista. La tercera razón de la crisis marital pudo haber sido la avanzada enfermedad de Rafael que lo fue sumiendo en una progresiva psicosis medular e hizo imposible sostener la convivencia marital. Alguna de las tres anteriores, o todas juntas, fueron las probables razones de la ruptura marital entre Rafael Montes de Oca y María Ríos Cárdenas.

En los siguientes tres años (1927 a 1929) la revista de María Ríos se convirtió en una de las más famosas de la época, era una publicación de vanguardia en todos los sentidos, así que María pasó de ser enfermera cuidadora de un sifilítico a una de las plumas feministas más reconocidas; se relacionó con múltiples grupos de mujeres en México, Estados Unidos y Argentina; desarrolló proyectos muy importantes como entrevistar a las mujeres más brillantes de México, lanzar y patrocinar un concurso que buscaba a las mujeres más relevantes de la vida pública de México intitulado "La mujer más inteligente de México", así como escribir múltiple artículos sobre familia, salud, higiene, matrimonio, divorcio y trabajo femenino. También se dejó seducir por el teatro y escribió crónicas llenas de una enorme pasión y se vinculó con figuras de la política nacional, lo que le permitió ser representante del sector femenil en el Partido Nacional Revolucionario, imagen pública que a la vuelta de algunos años le permitió convocar a los congresos feministas Nacional de Obreras y Campesinas de 1931 y 1932 y escribir en 1942 su obra más importante, La mujer mexicana es ciudadana, texto fundacional del movimiento feminista mexicano y que la convirtió en una de las más fieles luchadores del voto femenino. No cabe duda que María Ríos Cárdenas (1942) desarrolló nuevas cualidades en su faceta de feminista, en las que contó con profesionalismo, audacia, inquietud, diplomacia y negociaciones con las esferas del poder y una fuerza de individualidad muy marcada. Fue una mujer de poder que supo luchar por los derechos de las mujeres $y$, en muchas circunstancias, como en el mundo laboral, demandó derechos iguales a los de los varones. Dichas cualidades la han con- 
vertido en una de las feministas más biografiadas por la historiografía, pero hasta ahora se desconocía su pasado de esposa-enfermera de un sifilítico. ${ }^{35}$

A través de su revista, María se sumó a las campañas antisifilíticas de la dictadura sanitaria del gobierno y constantemente publicó artículos de la "Sección de Propaganda y Educación Higiénica del Departamento de Salubridad Pública de México". Pero también de su propia pluma escribió el texto "Peligrosa sífilis contagiosa", en el que daba infinidad de consejos a las jovencitas para no casarse con hombres sifilíticos y les indicaba cómo prepararse para su importante papel de esposas y madres. No deja de ser escalofriante pensar en las imágenes que pasaron por la mente de María cuando escribió el siguiente párrafo,

[...] la sífilis es eminentemente contagiosa, la persona que la sufre puede transmitirla con la mayor facilidad, en un beso, cuando se utilizan objetos infectados por los enfermos, como vasos, tohallas, cepillos, etc. y cuando un enfermo se descuida y llega la sífilis a cierto grado, los estragos en el individuo son terribles, porque ataca absolutamente a todo el cuerpo y es causa de grandes sufrimientos, entre otros: la parálisis y la locura... Todo esto puede evitarse, cuando tanto el hombre como la mujer, conscientes de sus altos deberes en relación con la maternidad, procuren elegir por cónyuge a una persona sana. ${ }^{36}$

¿Qué estaba pensando en realidad al redactar este párrafo?, ¿cada vez era mayor su desprecio hacia Rafael? De cualquier manera, ya se había transformado en algo muy distinto de lo que Rafael necesitaba en esos últimos años de su vida. Lo que sí es un hecho es que a mediados de 1927 la pareja elaboró conjuntamente un convenio de divorcio por mutuo consentimiento -según lo señala la propia María en su demanda de divorcio-, lo que significa que platicaron pacíficamente la disolución del matrimonio y llegaron a ciertos acuerdos, pero por razones desconocidas las negociaciones se rompieron y llegó la batalla final.

La ruptura del matrimonio se puede constatar desde principios de 1927 cuando dejaron de habitar el acogedor domicilio conyugal del jardín y pla-

${ }^{35}$ Las historiadoras que han trabajado a María Ríos Cárdenas son: Ramos Escandón (1998); Tuñón (2002); Salguero Báez (2000, s. a. y 2007).

36 "Higiene y Salud", Mujer. Periódico Independiente para la Elevación Moral e Intelectual de la Mujer. Revista Mensual Ilustrada, año 2, núm. 3, 1 de marzo de 1927, p. 11. 
zuela de Santiago en Tlatelolco, en donde Rafael había vivido por 20 años, y se trasladaron a un incómodo y pequeño departamento en la calle de Allende que María pagó con las ganancias de la empresa de plumaje de la que se vanagloriaba de ser propietaria.

Unos días antes de que María presentara la demanda de divorcio necesario, Rafael firmó distintos documentos notariales en los que se fue deshaciendo de toda su fortuna, en enero de 1928 firmó el reconocimiento de una deuda en un documento de Protesto de un pagaré por el exorbitante monto de 15000 pesos oro. ${ }^{37}$ Desconocemos las razones de tales acciones, bien pudo haber sido para evitar que en el divorcio María le quitase la mitad de los gananciales, o también pudo haber sucedido que Rafael entró en una etapa crónica de psicosis medular.

De cualquier manera, el mismo año en que se aprobó el nuevo Código civil de 1928 que incorporaba las nuevas disposiciones de la dictadura sanitaria, María presentó la demanda de divorcio necesario el 21 de marzo de 1928 acusando a su marido de haberse infectado de sífilis debido a su vida disipada y con toda la mala intención mintió al decir que al momento de contraer matrimonio ella desconocía que su marido estuviese enfermo de sífilis. La guerra ya fue de confrontación y sin cuartel, así que, a los dos días siguientes, el 23 de marzo, Rafael elaboró su tercer y último testamento en el que le quitó todo a María y dejó toda su fortuna a su hijo natural, y si este llegase a fallecer la herencia pasaría a su nuera y cuatro nietos. ${ }^{38}$

El hecho de quedarse sin el sustento económico de la fortuna de su marido tuvo que haber sido un duro golpe para María, pues a pesar de sus múltiples esfuerzos, y de haber subido el precio de su revista suplicando la ayuda de sus amables lectoras, ${ }^{39}$ sólo pudo mantener su querida revista un año y medio después de su ruptura "sentimental" con Rafael y en diciembre de 1929 -cuando todavía no se emitía la sentencia final de su divorcio- se despidió de sus lectoras con estas tristes pero combativas palabras,

${ }^{37}$ Notario 40. Ramón Cosío González. Vol. 74, 17 de marzo de 1928, fs. 81-82. Escritura 3644. Protesto. Juan Suárez Ramírez a Rafael Montes de Oca. AHNCM, México.

${ }_{38}$ Notario 40. Licenciado Álvaro Ysla encargado. Vol. 73, 23 de abril de 1928, fs. 136-138. Escritura 3698. Testamento y revocación Rafael Montes de Oca. AHNCM, México; TsjDF. Cárdenas, 1928. Exp. 399734. AGn, México.

${ }^{39}$ María Ríos Cárdenas, "A los suscriptores y al público en general”, Redacción. Mujer. Periódico Independiente para la Elevación Moral e Intelectual de la Mujer. Revista Mensual Ilustrada, año 1, núm. 11, 1 de noviembre de 1927, p. 3. 
Hace tres años, el día 12 de diciembre de 1926, apareció por primera vez la Revista MUJER, dirigida y administrada por un grupo de muchachas. Con escasos recursos, pero con un programa nuevo y con mucha fe en el triunfo, me lancé a luchar por sostener un periódico de ideas avanzadas, como son las del feminismo... A últimas fechas y para llevar a cabo un balance general de los ingresos y egresos habidos durante tres años que lleva de vida activa la Revista: con objeto de precisar las fuerzas con que cuento; así como las bases sólidas sobre las que deberá descansar en lo futuro el periódico; y en mi justo deseo de que la Revista MUJER tenga oficinas y a ser posible talleres propios, hago un alto en el camino, interrumpiendo la publicación de esta Revista, para reanudarla cuando estime necesario por haberse realizado para entonces los proyectos que menciono... Expresadas las razones anteriores por las que voy a suspender, temporalmente, la publicación de "MUJER" y los proyectos que hay en cartera para beneficio del periódico, sólo me resta manifestar nuevamente mi agradecimiento por las finezas y atenciones de que he sido objeto por parte de los anunciantes, subscriptores y público en general y me despido con un HASTA DESPUÉs. ${ }^{40}$

En lo que respecta a Rafael, resulta muy penoso seguir sus actuaciones a lo largo de las más de 200 hojas del expediente del pleito judicial, pues sus acciones fueron erráticas y estuvo pésimamente asesorado por sus abogados. Durante todo el litigio una y otra vez cometió múltiples errores, siempre contestó de forma tardía y extemporánea los distintos autos, presentó fuera de tiempo sus pruebas y omitió muchas formalidades jurídicas que lo fueron dejando en desventaja en relación con su hábil y astuta consorte. Pareciera que Rafael ya presentía su derrota en el divorcio y por eso se deshizo de todos sus bienes. ${ }^{41}$

Un asunto relevante del juicio y que coincide con la invasiva política de la dictadura sanitaria fue que todas las personas vinculadas al juzgado y al juicio -magistrados, jueces, abogados, ministerio público, testigos, oficiales, médicos, etc.- estuvieron enterados de que Rafael Montes de Oca padecía una sífilis medular en tercera etapa. El propio Rafael nunca se preocupó por defender su honor ni negar su enfermedad, más bien a lo largo de todo el

40 María Ríos Cárdenas, "Nuestro 3er Aniversario”, Mujer. Periódico Independiente para la Elevación Moral e Intelectual de la Mujer. Revista Mensual Ilustrada, año 3, núm. 3, 1 de diciembre de 1929 , p. 2.

${ }^{41}$ Notario 40. Vol. 75, 28 de abril de 1928, fs. 115-118. Escritura 3710. Compraventa Rafael Montes de Oca e Ygnacio Ocampo y Amezcua. AHncm, México. 
proceso se empeñó en convencer al juzgado de que padecía dicha enfermedad desde inicios del siglo, por lo que se infectó antes de contraer matrimonio. Lo cual era cierto, pero no deja de ser insólita la transparencia con la que Rafael se presentaba ante el juzgado. ¿Qué tan humillante pudo haber sido para un hombre como él insistir que había estado enfermo de sífilis durante muchos años y que su esposa se casó con él sabiendo la enfermedad que padecía? Si en esa época la gente insistía en ocultar un mal tan vergonzoso, Rafael no tuvo empacho en abrirlo públicamente. Este extraordinario comportamiento de Rafael fue condenado por María con estas palabras: "con desvengonzante cinismo confiesa estar enfermo de sífilis medular desde antes del matrimonio" ${ }^{42}$

El juicio de divorcio fue muy prolongado, duró de marzo de 1928 a enero de 1930, incluyó tres distintos procedimientos, un juicio de recusación, una apelación y una revisión en segunda instancia. Finalmente, el último fallo de la Primera Sala del Tribunal Superior de Justicia fue conceder el divorcio a favor de María, mandar la repartición de bienes gananciales y la obligación de Rafael Montes de Oca de dar una pensión alimenticia a su exesposa. Desconocemos qué pasó después del juicio, o si se ejecutó la sentencia o aplicó el descuento de la pensión. Ni siquiera sabemos cuánto tiempo más sobrevivió Rafael a este último y lastimoso proceso de su vida.

Tal vez para Rafael lo más doloroso de esta etapa de decadencia no fue perder a su esposa-enfermera, ni deshacerse de su fortuna, ni siquiera perder su juicio de divorcio; lo más doloroso para Rafael Montes de Oca fue perder la dominación sobre sí mismo, su salud se deterioró a tal grado que ya no pudo producirse a sí mismo con nuevas tecnologías del yo, su cuerpo estaba derrotado, la muerte lo acechaba, ya no pudo volver a fijar su identidad en función del conocimiento de sí mismo ni lograr reconstruirse sin María. Por lo que al tiempo que se emitió la sentencia del divorcio también perdió el poder de su propia subjetivación. Toda su larga experiencia de vida y su incansable lucha en contra de una enfermedad devastadora no le sirvieron de mucho. La muerte lo fue aislando de todo, pues como dice Norbert Elias (1989), "los que están aquejados de dolores se van quedando solos" (p. 8).

Cada vez que Rafael asistía al juzgado para la realización de algunas de las audiencias del divorcio causaba gran impacto entre el personal del tribunal, pues no sólo veían a un hombre extremadamente longevo sino también a un cuerpo lento, cansado, torpe y enfermo, su fragilidad y dependencia eran cre-

42 TSJDF. Cárdenas, 1928. Exp. 399734. AGN, México. 
cientes; como dice Foucault, entre mayor es la anomalía mayor es el rechazo social. Entonces, surgieron crecientes rumores sobre la historia del divorcio de la feminista y su marido sifilítico, y en el diario La Prensa del 10 de mayo de 1929 se publicó la siguiente nota: "Nos sorprendió grandemente [...] la enfermedad del señor Montes de Oca, porque hemos tenido oportunidad de verlo y es un hombre que a leguas revela la ataxia locomotriz. Su andar es difícil y si se miran sus firmas en el expediente del juzgado, se ve que casi es inteligible su letra." ${ }^{43}$

Poco a poco, Rafael ya no fue capaz de decidirse a sí mismo y la más clara manifestación de ello fue cuando alguien más tuvo que firmar a nombre de él, bajo la forma judicial de “A ruego y encargo de...". Ya no podía presentarse a sí mismo, ni hablar por sí mismo, ni siquiera firmar por sí mismo. Su firma es precisamente el mejor testigo de esa decadencia entre marzo y octubre de 1928 , como se observa en las imágenes 1-4 donde comparamos las firmas de Rafael durante un semestre y finalmente a partir de octubre ya no pudo firmar.

Como epílogo podemos señalar que diez años después de la sentencia de 1930 se comenzó a usar la penicilina de manera eficiente en el combate contra la sífilis. Desde entonces, dejó de ser la temida y mortal enfermedad que durante siglos mantuvo a raya las prácticas sexuales de muchas personas de todos los grupos sociales.

\section{CONSIDERACIONES FINALES}

¿Cómo podemos considerar los más de 68 años de vida de Rafael Montes de Oca? Aunque fue una vida muy longeva, la mitad de su existencia la vivió enfermo de sífilis. Durante tantos años pudo sentir en carne propia el cambio entre dos momentos históricos de la salud pública en México: de la moderada política de salud pública del porfiriato que todavía respetaba los valores del secreto médico, hacia la dictadura sanitaria de la posrevolución que persiguió a los cuerpos sifilíticos.

¿Qué sentido tuvo haberse enfermado de sífilis? No cabe duda de que dicha enfermedad fue un parteaguas para Rafael, las metas, los objetivos y los logros que se pudo haber creado antes de la enfermedad tuvieron que transformarse radicalmente. Como lo pudimos ver a lo largo de su historia, gracias

43 "Una nueva tragedia del matrimonio", La Prensa. Diario Ilustrado de la Mañana, t. 1, núm. 253, viernes 10 de mayo de 1929. 


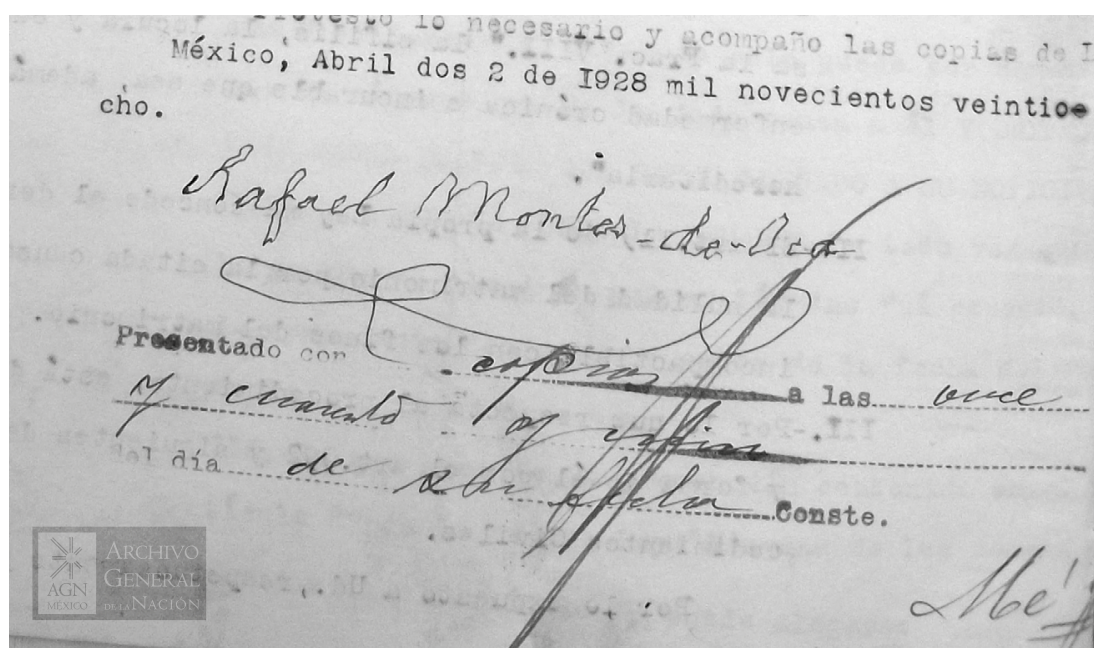

Imagen 1. Firma del 2 de abril de 1928.

Archivo General de la Nación, fondo TSJDF, sección Juicios ordinarios civil, vol. Juicio de divorcio Ríos Cárdenas de Montes de Oca, María vs. Rafael Montes, 1928, exp. 399734, caja 2193, f. 11v.

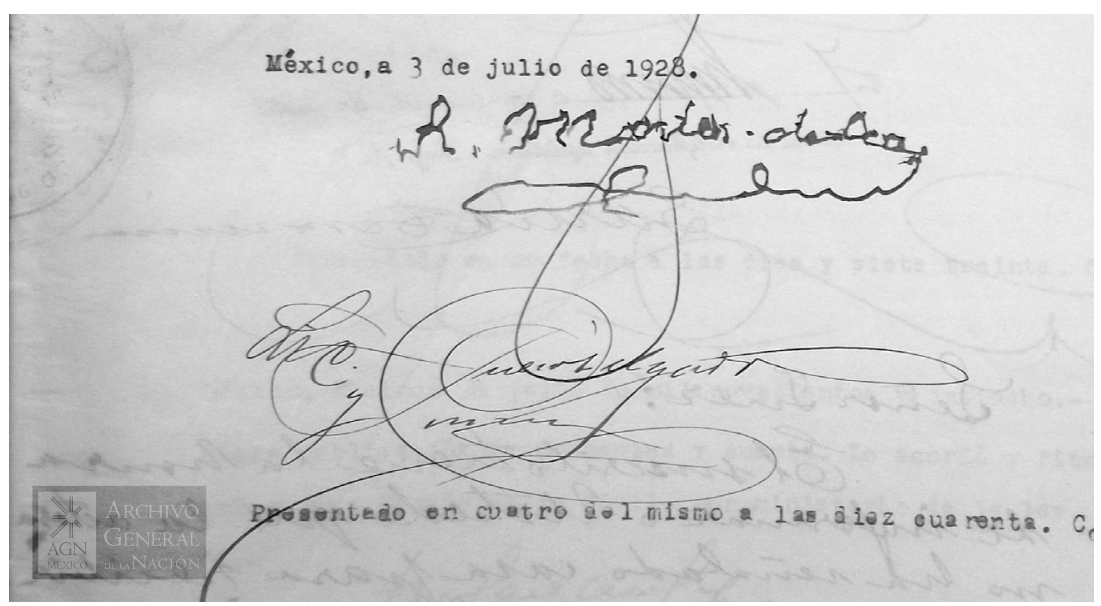

Imagen 2. Firma del 3 de julio de 1928.

Archivo General de la Nación, fondo TSJDF, sección Juicios ordinarios civil, vol. Juicio de divorcio Ríos Cárdenas de Montes de Oca, María vs. Rafael Montes, 1928, exp. 399734, caja 2193, f. 23. 


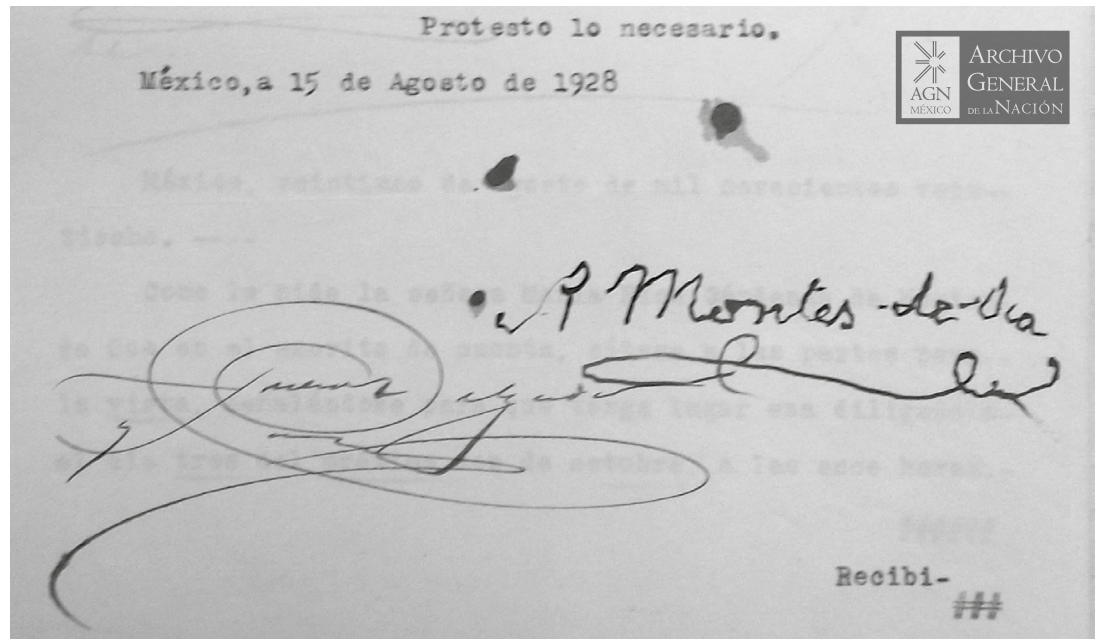

Imagen 3. Firma del 15 de agosto de 1928.

Archivo General de la Nación, fondo TSJDF, sección Juicios ordinarios civil, vol. Juicio de divorcio Ríos Cárdenas de Montes de Oca, María vs. Rafael Montes, 1928, exp. 399734, caja 2193, f. 7 .

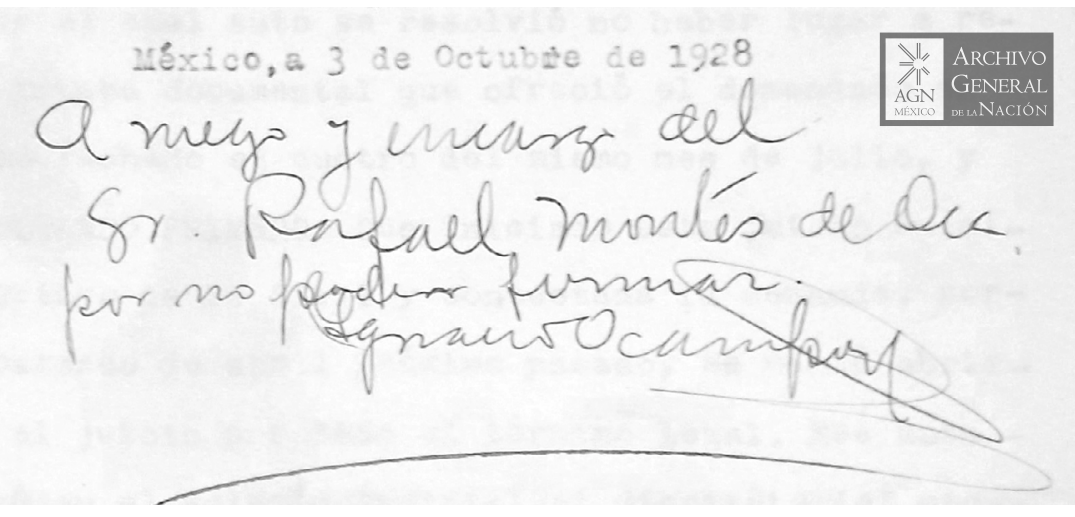

Imagen 4. Firma del 3 de octubre de 1928.

Archivo General de la Nación, fondo TSJDF, sección Juicios ordinarios civil, vol. Juicio de divorcio Ríos Cárdenas de Montes de Oca, María vs. Rafael Montes, 1928, exp. 399734, caja 2193, f. 14. 
a la sífilis Rafael realizó una constante resignificación de su propia subjetivación. Vivió una vida de sifilítico en revisión permanente y cuidó de sí mismo durante más de 20 años. Si en 1918 se autodefinía como industrial y cuatro años después se autonombraba como comerciante, nueve años más tarde, en 1926, realizó la mayor de las transformaciones al convertirse en artista. Así que vivió constantes procesos de desidentificación y nuevas subjetivaciones en los que también fueron cambiando los objetivos y logros de su vida. Gracias al arte pudo alejarse por momentos de su lastimera sífilis terciaria, y dedicar sus debilitadas capacidades en el gozo de la creación escultórica. Durante esos momentos, como señala Foucault (2010), le dio a su existencia una forma totalmente distinta, "una forma que es la verdadera vida" (p. 200).

Aunque la ciencia médica y la política de salud pública de la época que vivió Rafael le impusieron una degradante identidad a su cuerpo sifilítico y lo objetivaron como decadente y degenerado condenándolo a vivir marginado de la sociedad, él confrontó a los poderes públicos cuando, a pesar de las estrictas prohibiciones, pudo casarse y resignificar la institución matrimonial de una forma muy distinta al discurso eugenésico en boga. Así que, en plenas campañas antisifilíticas, Rafael no se entregó a la renunciación de la vida, ni obedeció la norma de separar a los enfermos de los sanos, y más que esconderse y ocultarse, construyó su propio proceso de autogobierno y de prácticas del yo al cuidar constantemente de sí mismo en una subjetivación procesual.

No cabe duda de que la convivencia por diez años entre Rafael Montes de Oca y María Ríos Cárdenas fue un parteaguas fundamental para la vida de ambos. Gracias a su esposa-enfermera, Rafael pudo resignificar su vida. La convivencia con ella, fincada, probablemente, en un cierto afecto de camaradería y una significativa resonancia sentimental entre los dos fue de crucial importancia, le ayudó a redefinir sus cambios identitarios. Pero en la etapa final de su vida, la esposa-enfermera dejó de ser suya para convertirse en una exitosa debutante del feminismo mexicano. Como dice el cuento de Emilia Pardo que hemos parafraseado, "la enfermerita dejó las enaguas y se puso los pantalones de su marido" (Pardo, 1909, pp. 49-51).

Claro que nos quedan diversas interrogantes: ¿ella sólo fue su enfermera?, ¿en las épocas de recuperación de Rafael tuvieron algún tipo de convivencia sexual?, ¿ella quedó contagiada? Se supone que una sífilis avanzada es muy difícil que se contagie; además, como ya se señaló líneas arriba, se supone que ella no se infectó de sífilis. Pero entonces, ¿Rafael y María renunciaron a su vida sexual activa y dirigieron su fuerza libidinal al movimiento feminis- 
ta y a la creación artística, respectivamente?, o lo que es peor, ¿Rafael siguió acudiendo al servicio de meretrices aun después de haber sido diagnosticado con sífilis y María tuvo amores escondidos? Lamentablemente, no podemos responder dichas interrogantes.

De cualquier manera, la biografía de María Ríos Cárdenas, tan profusamente trabajada por la historiografía feminista, todavía tiene un capítulo por escribirse que considere su etapa previa al momento de convertirse en feminista activa. Fue una mujer de combate, que supo luchar por un espacio en el mundo profesional de la enfermería, y que también aprovechó la ocasión de un matrimonio de interés que le permitió acceder a un mejor estatus económico. ¿Cómo podemos ir construyendo su propio proceso de subjetivación?, ¿interesada, pragmática, idealista, solidaria, comprometida con las causas de las mujeres, inteligente, hábil estratega política? Falta mucho por escribir sobre María Ríos Cárdenas.

Finalmente, sólo nos queda reflexionar sobre la muerte de Rafael Montes de Oca. Aunque desconocemos la fecha de su deceso suponemos que fue muy cercano al fallo final de su divorcio en 1930. De cualquier manera, sería pertinente preguntarnos sobre si existió acaso alguna relación entre su forma de vivir y su forma de morir. No deja de ser lastimoso reflexionar que el enorme cuidado que puso en su subjetivación procesual por casi 20 años se haya visto perturbado por la descarnada lucha que comenzó contra María después de 1927 y, sobre todo, que haya pasado cuando la vejez y la enfermedad lo estaban matando. No sabemos cómo murió, pero como dice Norbert Elias (1989), aunque es imposible compartir con nadie el proceso de morir (p. 75), podemos expresar la idea de que con su muerte se cerró el pequeño mundo de su propia y longeva vida, de su subjetivación procesual, de sus sentimientos, experiencias y sueños de artista que sólo él conocía. Y todo esto desapareció para siempre junto con el cuerpo sifilítico de Rafael Montes de Oca.

\section{LISTA DE REFERENCIAS}

Alba-Hernández, F. (1976). La población de México. México: El Colegio de México/ CEYED.

Barbosa Cruz, M. (1 de agosto de 2003). Insalubres e inmorales: alojamientos temporales en la Ciudad de México, 1900-1920. Scripta Nova, ViI(146:053). Recuperado de http://www.ub.edu/geocrit/sn/sn-146(053).htm 
Carranza, V. (1917). Ley Sobre Relaciones Familiares, expedida por el C. Venustiano Carranza, Primer Jefe del Ejército Constitucionalista, encargado del poder ejecutivo nacional. México: Edición Oficial.

Carrillo, A. M. (2010). Control sexual para el control social: la primera campaña contra la sífilis en México. Revista Espaço Plural, xI(22), 65-77. Recuperado de http://e-revista.unioeste.br/index.php/espacoplural/article/view/4835

Carrillo, A. M. (2002). Surgimiento y desarrollo de la participación federal en los servicios de salud. En G. Fajardo Ortiz, A. M. Carrillo, R. Neri Vela, Perspectiva histórica de atención a la salud en México, 1902-2002 (pp. 17-66). México: UNAM.

Elias, N. (1989). La soledad de los moribundos. México: FCE.

Estrada Urroz, R. (2007). ¿Público o privado? El control de las enfermedades venéreas del porfiriato a la revolución. Estudios de Historia Moderna y Contemporánea de México, 22, 33-55. Dor: http://dx.doi.org/10.22201/iih.24485004e.2007.033.3157

Foucault, M. (2008). Tecnologías del yo y otros textos afines. Buenos Aires: Ediciones Paidós/Ibérica.

Foucault, M. (2010). El coraje de la verdad. México: FCE.

García Peña, A. L. (2016). Conflictos conyugales durante el porfiriato: los extranjeros y el divorcio de Francisco Cosmes. En P. Gonzalbo y L. Mayer (coords.), Conflicto, resistencia y negociación en la historia (pp. 153-182). México: El Colegio de México.

Gastelum, B. (1926). La persecución de la sífilis desde el punto de vista de la garantía social (36 pp.). México: Departamento de Salubridad Pública.

Ginzburg, C. (2010). Apéndice. Pruebas y posibilidades. Posfacio a Natalie Zemon Davis, Il Ritorno di Martin Guerre. Un Caso di Doppia Identitanella Francia del Cinquecento, 1984. En El hilo y las huellas: lo verdadero, lo falso y lo ficticio (pp. 433465). México: FCE.

González Ureña, J. (1 de septiembre, 1906). Sifilografía. Algunas observaciones sobre la sífilis en México. Gaceta Médica de México, I(9), Tercera Serie.

Guattari, F. (1996). Caosmosis. Buenos Aires: Manantial.

Inauguración de la Campaña Nacionalista Antivenérea (1927). Boletín del Departamento de Salubridad Pública, 1, 162-174. México: Editorial Cvltura.

Lavalle Carvajal, E. (febrero, 1911). Sifilografía. La lucha contra las enfermedades venéreas. Gaceta Médica de México, VI(2), tercera serie, 56-65.

Leitner, R. M. C., Körte, C., Edo, D. y Braga, M. E. (2007). Historia del tratamiento de la Sífilis. Revista Argentina de Dermatología, 88(1), 6-19. Recuperado de http://www. scielo.org.ar/scielo.php?script=sci_arttext\&pid=S1851-300X2007000100001\&ln$\mathrm{g}=\mathrm{es} \&$ tlng=es [Consulta: 27 de marzo de 2018.] 
Moreno Guzmán, A. (enero-febrero, 2016). Síntesis histórica de la Escuela Médico Militar. Plantel emblemático del cemicsa. Revista de Sanidad Militar, 70(1), pp. 152-168.

Moreno Guzmán, A. (marzo-abril, 2017). Los edificios de la Escuela Médico Militar en cien años de historia. Revista de Sanidad Militar, 71(2), pp. 105-122.

Natividad Almirón, V. (junio, 2016). Las discusiones médicas sobre el certificado prenupcial en Latinoamérica: Brasil, México y Perú. Revista de la Red Intercátedras de Historia de América Latina Contemporánea, 2(4), pp. 90-103.

Otero, M. (abril, 1910). Sifilografía. Breves apuntes acerca del suero diagnóstico de la sífilis. Gaceta Médica de México, v(4).

Pardo Bazán, E. (1909). Dípticos. Cuentos, 1895-1909. Recuperado de: http://www.ellibrototal.com/ltotal/ficha.jsp?idLibro=1589

Ramos Escandón, C. (marzo, 1998). María Ríos Cárdenas: ciudadanía y derechos políticos en una época de crisis, 1920-1940. Fem. Publicación Feminista Mensual, 22(180), 14-18.

Raso, E. del (julio, 1919). Suero diagnóstico de la sífilis. Gaceta Médica de México, 64(I), pp. $17-23$.

Ríos Cárdenas, M. (1942). La mujer mexicana es ciudadana: historia con fisonomía de una novela de costumbres. México: A. del Bosque.

Salguero Báez, R. L. (2000). La revista Mujer. Periódico Independiente para la Elevación Moral e Intelectual de la Mujer, 1926-1929 y el feminismo en la Ciudad de México en los años veinte (2 vols.). (Tesina de licenciatura), Universidad Autónoma Metropolitana-Iztapalapa, México.

Salguero Báez, R. L. (s. a.). La revista Mujer. Periódico Independiente para la Elevación Moral e Intelectual de la Mujer, 1926-1929. Recuperado de http://redestudiosprensa. $\mathrm{mx} / \mathrm{hdp} /$ files/117.pdf

Salguero Báez, R. L. (2007). De Sabinas, Coahuila, al corazón del país. María Ríos Cárdenas, periodista feminista en tiempos posrevolucionarios. IV Encuentro Internacional de Historiadores de la Prensa en Iberoamérica. Red de Estudios sobre Prensa. Recuperado de http://redestudiosprensa.mx/hdp/files/179.pdf

Suárez, F. C. (diciembre, 1917). Profilaxis de la sífilis. Revista del Ejército y Marina, 742-747.

Torres Barrea, S. y Zambrano-Lizárraga, E. (2010). Breve historia de la educación de la enfermería en México. Revista de Enfermería del Instituto Mexicano del Seguro Social, 18(2), 105-110.

Tuñón, J. (mayo-agosto, 2002). ¿Convicción o táctica? Atrevimiento y precaución en el primer feminismo mexicano (1873-1935). Dimensión Antropológica, 25, 9-58. 
Turnes, A. L. (2007). La sífilis en la medicina. Una aproximación a su historia, Montevideo: Ediciones Granada. Recuperado de https://www.smu.org.uy/publicaciones/ libros/textocompleto/la_sifilis_medicina.pdf

Vera Bolaños, M. y Pimienta Lastra, R. (2001). La acción sanitaria en el Estado de México, 1824-1937. Política y Cultura, 16.

Villeda García, F. L., Rodríguez-González, N. y Córdova-Ávila, M. Á. (2010). La práctica enfermera durante la revolución mexicana (1910-1920). Revista de Enfermería del Instituto Mexicano del Seguro Social, 18(3), 163-166.

\section{OTRAS FUENTES}

\section{Bibliografía}

Aquino Moreschi, A. (2013). La subjetividad a debate. Revista de Sociología, 28(80), 259-278. Recuperado de http://www.sociologicamexico.azc.uam.mx/index.php/ Sociologica/article/view/37 